\title{
THE PASSING OF THE LEGAL PROFESSION
}

One of the largest, if not the largest, associations of lawyers in this country, recently dropped from its roll eight hundred and sixty-nine members for failure to pay their annual dues. Many of them, the association's report states, did not want to be dropped, but could not spare the moderate sum of ten dollars per year. This was a most startling report and caused many to ask, "Why are so many members of the legal profession in such an impecunious condition?" The answer to the question is "changed conditions". The practice of law has become conlmercialized. It has been transformed from a profession to a business, and a hustling business at that. Financial interests have looked upon the legal profession with longing eyes, and have gradually corralled it and brought it under their domination for the profits which can be acquired from it. Within the recollection of men living, the practice of law was conducted by the lawyer, a man who was looked up to in the community as a member of a dignified profession, a leader in politics and society. To-day the practice of law is not carried on by the lawyer except in a limited way. The great bulk of litigation, while it may be actually done by a lawyer, or a man who has been admitted to the Bar and is entitled to call himself a lawyer, is conducted by corporations which have neither soul nor conscience, and owe allegiance to no code of ethics or morals, and which have no other cause for existence than the accumulation of wealth for directors and stockholders. The lawyer's former place in society as an economical factor has been superseded by this artificial creature of his own genius, for whom he is now simply a clerk on a salary.

I.

One of the most lucrative branches of the lawyer's practice was formerly real estate law. When a man bought a piece of real estate he employed a lawyer to search the title, and tell him whether it was good or not. If a man had money to loan on bond and mortgage, he turned it over to his lawyer to make the loan and search the title. To-day the real estate lawyer is a thing of the past. If a man buys a house he does not go to his. lawyer. He goes to a Title Company. The company searches 
his title, a lawyer may do the actual work. The client pays a fee for legal services, which fee goes, not to the lawyer who did the work, but to the company which hires the lawyer, and is distributed by the company in the shape of dividends to the stockholders who are not lawyers and perhaps do. not know a mortgage from a mechanic's lien, and do not even know the names of the corporation's clients. If a man has money to loan today on bond and mortgage, he goes to some Title Company or to one of its auxiliaries, called a Mortgage Company. The Mortgage Company will sell and assign to him a mortgage all placed, the title all searched. The Mortgage Company, or the Title Company, has already made the legal fees out of the borrower for searching, and perhaps a brokerage commission besides for loaning its own money, and it now sells the mortgage to the prospective investor and insures its collection for one-tenth of the income. If the mortgagor fails to pay his interest the Mortgage Company undertakes the foreclosure. One of its own clerical force, a member of the Bar, appears as the attorney of record, and the costs which are taxed and the allowances which the Court makes, supposing and assuming him to be a lawyer exercising the functions of such, go, not into the pockets of the lawyers for whose compensation they are intended, but into the treasury of the Mortgage Company to swell the dividends of its lay stockholders.

It has been estimated that ten million dollars are paid annually by real estate interests in New York City alone, into the coffers of the Title Insurance Companies and Mortgage Companies. These ten million dollars are paid, strictly speaking, for legal services, but only a small portion of the amount paid actually reaches the legal profession.

These companies gained their foothold in the confidence of the investing public because of the insurance feature of the contracts which they issue, and when such companies first came into existence they did insure titles, but to-day title insurance is more of a myth than a reality. Let any holder of a policy of insurance upon his property which has been issued within the last ten years, examine it carefully and he will find that every possible flaw or chance of dispute affecting his title is excepted and not covered by his policy, and that the policy, so-called, covers nothing but what is so absolutely certain that no insurance is required upon it. What the policy-holder gets and what he pays for is in 
reality a search made by clerks of the corporations who may or may not be lawyers, and whose salaries amount to but a small portion of the fee which he pays.

These Real Estate Companies have increased the general scope of their business from time to time so that they now possess all the powers of banks and trust companies and act as guardians, trustees, executors, etc. They are not limited by any code of ethics which prevents them from soliciting business. One such company in New York went so far recently as to display advertisements offering to draw wills free, provided it was named as. executor of the testator's estate.

They are not forbidden to pay a monetary consideration for having legal business placed in their hands.

If a lawyer offered a monetary consideration to have legal business placed in his hands, he would be guilty of a misdemeanor and liable to disbarment; at least that is true in New York State.

Another line of legal work which Real Estate Companies have found lucrative is in relation to what are known as condemnation proceedings. When a street or park is to be opened, or land is. to be taken for other public purposes, it is necessary for the land owners to be represented by counsel in what are commonly known as "condemnation proceedings". Title Companies first came into this business to search the titles, but, realizing that the legal profession was also making money, and following their natural corporate instinct, they proceeded to take up the legal end. One of these companies in New York, I am informed, has, or at least had, in its office a separate department known as its "Condemnation Proceedings Department". It employed" solicitors to interview real estate owners whose property was about to be condemned, and undertook the entire procedings, employing attorneys on a salary, who appeared ostensibly as the attorney of record for the different land owners.

In the annual report of the Insuranice Commissioner of New York for I9Io, one of these companies included in its report the following:

"Assets, condemnation proceedings, awards and accrued interest............. $\$ 736,316.97$ "

At the bottom of the page appears the following foot note by the Commissioner:

"The company carries on its book as an asset the sum of $\$ 723,412.24$ representing the estimated value of condemnation proceeding contracts." 
And further on in its report the company says:

"Condemnation proceedings, drawing papers, examining titles, recording fees and surveys $\ldots . \ldots \ldots \ldots \ldots \ldots \ldots \ldots \ldots$........... $\$ 83,902.45 "$

I asked the manager of the Condemnation Proceedings Department of this company once how he justified the conduct of his company, and he informed me that they had purchased an old charter of some other company which permitted it to do just what it was doing.

Assuming that this old charter is so drawn as to apparently enable the company to do what it is doing, is such charter legal? The Court of Appeals in New York has recently said that a corporation could not be organized to practice law, even before the enactment of the present statute which specifically prohibits it, and which statute is quoted at length further on.

\section{II.}

Another lucrative branch of the lawyer's practice, which has been captured by the corporations, is the defense of negligence cases. Nearly every employer to-day carries what is commonly called "Liability Insurance" with some insurance company, but which, in reality, is a contract by the corporation to defend his litigation, with a proviso annexed that if the litigation is unsuccessful, the corporation will pay the judgment rendered against him up to a certain limited amount.

The form of contract issued by all such companies is substantially the same. A sample policy of a company defending probably the largest amount of litigation in New York is before me, from which $I$ quote the following:

"III. To defend in the name and on behalf of the assured any suits which may at any time be brought against him on account of such injuries, including suits alleging such injuries and demanding damages therefor, although such suits, allegations or demands are wholly groundless, false or fraudulent.

IV. To pay all costs taxed against the assured in any legal proceeding defended by the company, all interest accruing after entry of judgment upon such part thereof as shall not be in excess of the limits of the company's liability as hereinafter expressed, all expenses incurred by the company for investigation, negotiation or defense.

$* \quad * \quad * \quad * \quad * \quad * \quad *$

D. The assured upon the occurrence of an accident shall give immediate written notice thereof to the company, or to its 
duly authorized agent, with the fullest information obtainable. He shall give like notice with full particulars, of any claim made on account of such accident. If, thereafter, any suit is brought against the assured he shall immediately forward to the company every summons or other process served upon him. The assured, when requested by the company, shall aid in effecting settlements, securing evidence, the attendance of witnesses and in prosecuting appeals. The assured shall not voluntarily assume any liability, settle any claim or incur any expense, except at his own cost, or interfere in any negotiation for settlement or legal proceeding without the consent of the company previously given in writing."

These companies, of course, cannot appear as attorney of record in actions which they undertake to defend, but the appearance is made by some member of the Bar usually employed by them on an annual salary. The attorney appearing in the action, we would doubtless learn if the truth could be ascertained, seldom sees the client or even knows who he is, and appears in such actions solely at the instigation of the company.

This contract, as appears upon its face, is a contract primarily to practice law, to defend litigation, and the insurance feature of it is simply an incident to the litigation. The company agrees to defend the action and defray the expenses, and if the litigation results adversely to the client, to pay any costs that may be taxed against him and to reimburse him to a certain extent. This is usually limited to five thousand dollars in the case of injury to one person, and the maximum liability growing out of any one accident is usually fixed at ten thousand dollars.

Some time ago, in talking with a lawyer who has been employed by one of these law-practicing companies a number of years, he tried to convince me that his company was doing what it had a legal as well as a moral right to do on the theory that the company was a guarantor and defending its own interests. I told him I could not agree with him because the insurance feature of his contract was a mere incident and the primary object the defense of litigation. Among other things, I asked him why his company did not confine itself to carrying on the business for which it was incorporated, to wit, insurance, and leave the defense of litigation to the legal profession. His reply was, "Because it is better business," and that is the substance of the situation in a nut-shell. Corporations have discovered that the practice of law is good business and in their effort to grasp it and conduct it upon business lines, have demoralized it as a profession. 
These insurance companies employ large forces of investigators and adjusters. On the happening of an accident they are sent out at once to gather the facts and make settlement with the injured party, to get rid of the claim in some way and at the least possible expense to the company. The injured employee is offered a small amount to sign a general release of all claims against his employer, and if coaxing and cajoling do not accomplish the desired results, more strenuous methods are resorted to.

I have before me a clipping from which it appears an ignorant Lithuanian laborer who was made totally blind because of an accident in defendant's factory, was induced by an admitted adjuster of one of these companies, assisted by a fellow countryman of the victim, to touch a pen with which a mark or signature was made at the end of a release on the supposition that the company was making him a loan and that he was signing a receipt. The fellow countryman of the victim, it seems, held himself out to the world as an independent adjuster of accident cases and was acting presumably for the plaintiff, although without knowledge of plaintiff's lawyer. This independent adjuster boarded in the same house with the victim, paid his board and bought him a ticket to. Cleveland on the day the supposed loan was made. The referee before whom the case came on an application to set aside the release, is quoted as saying, among other things:

"I cannot believe that Sautikus expended money in supporting, and purchasing railroad transportation for a man in whom he had no personal interest, without being in some manner reimbursed. The adjuster may have thought he was executing an effective stroke when he made this supposed settlement, but it was done in a careless and dangerous manner, one which does not usually commend itself."

To any lawyer familiar with the conduct of negligence litigation it needs no further evidence to convince him that Sautikus was also in the employ of the Insurance Company.

I was informed some time ago of a case where an injured employee was taken to a hospital and the adjuster, to force a settlement for an unconscionably small amount, went so far as to try to have the victim's family dispossessed, and offered to furnish a lawyer to conduct the proceedings and pay all expenses.

I once heard an adjuster of one of these Insurance Companies say to a lawyer, in substance, "I will give you so much for the case". The lawyer refused, and the adjuster replied, "Then we 
will settle with your client for less and you will get nothing"; to which the lawyer in return replied, "No, you won't; it is not: proper for you to go to my client and deal with him direct; it is. contrary to the ethics of our profession". At which the adjuster flared up and said, "To $\mathrm{H}$ - with ethics; we are not lawyers, we are a corporation practicing law for the money there is in it, and. we are going to settle the cheapest way".

The lawyer who appears in the case as the attorney for the defendant, of course, knows nothing about these settlements or efforts to compromise. The probabilities are he has never heard of the case. The settlements are made by laymen who, like the corporation, have neither ethics nor morals.

Workmen, as a rule, are without funds to retain a lawyer and can only avail themselves of legal services by making a contract to pay their attorney a contingent fee, a percentage upon the proceeds recovered. The practice of settling behind the attorney's back, after he has commenced an action, has become so notorious. that lawyers cannot afford to take a case on a contingency without making a contract for a much larger percentage than they otherwise would exact if it were not for the fact that they know that at least two-thirds of the cases will be settled without their knowledge or consent. The result of this is that the injured workman is between the Devil and the deep sea. The defendant; responsible for his injuries, will not pay him anything because he is insured and doesn't have to, or, at least, thinks he doesn't, until after a verdict has been rendered in excess of his policy. The Insurance Company will not pay him anything, their organization for defeating his claim is so perfect and their liabilities being lmited, they are willing to take chances on a trial if they cannot force a settlement for a small amount before trial is reached. He cannot get a lawyer to protect his interests without making a contract for usually one-half or one-third of the recovery instead of ten or fifteen per cent, which he might otherwise do if the lawyer. had any assurance that the case was to be tried on its merits or settled on his advice.

Just how many contracts these companies write a year it is. impossible to say as their reports to the Insurance Department show the volume of business in dollars and cents, and not in the number of contracts, and it is impossible to tell how many claims are made against them in the course of a year, because many of them are settled without suit, and many suits are settled before 
they actually.go on the calendar, and others are brought in minor. Courts not of record.

Some time ago I took the trouble: to. count up the number of cases on our Supreme Court calendar in New York County that was published.in October, rgro. The name of one attorney appeared in actions defended by one of these companies $38 \mathrm{r}$ times. This same attorney's name was used in actions defended by this company, not only in the Supreme Court but in the City Court and in the Municipal Courts and in the Supreme and County Courts in Kings County, and, I believe, also in Richmond, Queens, Nassau and Westchester Counties. I have been told that this company defends, on an average, in all Courts in New York City, at least 3,000 cases a year. This in itself would make it a physical impossibility for the attorney who appears for the 3,000 defendants, to know his own clients.

That the wholesale defense of such litigation is profitable, even with the maintenance and contingent limited indemnity provision annexed, is shown by the reports of these companies to the Insurance Department. I glean from the New York Insurance Commissioner's Reports of I910, the following:

Company No. I.

Income, Liability ....................\$5,236,370.52

Paid out for losses (net) ......... \$1,955,376.22

Investigating and adjusting claims... 931,570.34

Paid for commission (which means

for getting the business) $\ldots \ldots \ldots \ldots, 1,024,298.19$

Leaving a profit by practicing law......... \$I,325,I25.77

(Not a bad profit for one law office.) Company No. II.

Income, Liability . ................... \$3,6I9,585.82

Paid out for losses............ $\$ I, 716,884.21$

Investigating and adjusting claims... I64,593.3 I

Paid for getting the business....... 737,3 Io.62

Profits made by practicing law.............\$1,000,797.68. Company No. III.

Income, Liability . . . . . . . . . . . . . . $\$ 2,270,772.71$

Paid out for losses............ $\$ 759,505.60$

Investigating and adjusting claims... $330,830.65$

Paid for getting the business...... 432,208.79

I,522,545.04.

Profits made by practicing law........... $\$ 748,227.67$ 
The total amount taken away from the legal profession in one year, as shown by the New York Insurance Commissioner's Report of I9IO, by seventeen different corporations of this kind foots up $\$ 7,695,793.53$.

These companies have done more to create a class of lawyers and adjusters commonly known as "Ambulance Chasers" than any other one thing. They have not only robbed the legal profession but have debauched it as well.

\section{III}

I have before me a letter dated October 9, I912, reading as follows, the first word being fictitious:

DÖE ADJUSTMENT COMPANY. Mercantile Collections.

Dear Sir :

Re-Estate of........... Bankrupt. Our attorneys represent Mr. ....... of ......., one of the creditors of the abovenamed bankrupt, and in looking over the matter we find from the schedules that you also are one of the creditors of the bankrupt * * *. We think we can successfully prevent the bankrupt, through our attorneys, from securing his discharge from his debts.

If you are interested in this matter and would like to have our attorneys look after your interests, please advise us.

$$
\text { Respectfully yours, }
$$

DOE ADJUSTMENT COMPANY.

This letter is addressed to no one, and, from the fact that it is a faint carbon copy, was presumably sent to all the creditors of the bankrupt.

I also have before me a contract made by a Surety Company organized under the laws of New York, which by no process of reasoning can be said to be an insurance policy or an indemnity bond. It is a contract to practice law, pure and simple, not directly, but indirectly, but which under the decision of the Court of Appeals hereinafter quoted, is as illegal as if done directly.

The language of the contract is as follows, names being omitted:

"In consideration of the receipt of fifty dollars, and of the application for this contract, which is made a part hereof, the $\because \ldots \ldots$ Company of New York (hereinafter referred to as the Company) does hereby agree with ......... of ......... (hereinafter referred to as the Subscriber) to furnish its pro- 
tective service, for one year from and after the date hereof, to the Subscriber in the exercise of his actual exclusive rights by virtue of and under United States Letters Patent as follows, to wit:

Patent No. ..... dated ....... for ...........

while said letters patent are exclusively owned or controlled by the Subscriber and while this contract is in force, under the following terms and conditions, to wit:

I. In the event of apparent infringement of said patent, or any one of them, if more than one, the Company will, upon notification accompanied by satisfactory evidence thereof, at once communicate with the alleged infringer and cause to be sent to him all proper and desirable notices and demands, preliminary to suit, and use its influence and good offices in an effort to terminate such infringement and secure satisfactory adjustment and settlement of damages. In the event that the Company's warnings are not heeded, and the apparent infringement is continued, the Company agrees to furnish and provide counsel or attorneys for the institution and prosecution of a suit of infringement against the alleged infringer, in the proper Court, such suit to be prosecuted to final decree or mutually satisfactory settlement at the expense of the Company and without cost to the Subscriber other than the consideration paid for this contract."

This contract further provides among other things, that any costs which may be awarded to the client, shall belong not to the attorney who is furnished by the company, but to the company, and shall be assigned to it by the second party to the contract.

This contract was made in the City of New York subsequent to the enactment of Sec. 280 of the Penal Law of New York.

\section{IV.}

Is the conduct of litigation by these corporations legal?

In the year Igog the Legislature of New York passed an act (Chapter 483 of the Laws of Igog), which was amended by Chapter 3 I7 of the Laws of I9II, now constituting Section 280 of the Penal Law of New York, making it

"unlawful for any corporation or voluntary association to practice or appear as an attorney-at-law, for any person other than itself in any Court in this State or before any judicial body, or to make it a business to practice as an attorney-at-law, for any person other than itself, in any of said Courts or to hold itself out to the public as being entitled to practice law, or render or furnish legal services-or advice, or to furnish attorneys or counsel or to render legal services of any kind in actions or proceedings of any nature or in any other way or manner; or in any other manner to 
assume to be entitled to practice law or to assume; tise or advertise the title of lawyer or attorney, attorney-at-law, or equivalent terms in any language in such manner as to convey the impression that it is. entitled to practice law, or to furnish legal advice, services or counsel, or to advertise that either alone or together with or by. or through any it. has, owns, conducts or maintains a law office or an office for the practice of law, or for furnishing legal advice, services or counsel. It shall be unlawful further for any corporation or voluntary association to solicit itself or by or through its officers, agents or employees any claim or demand for the purpose of bringing an action thereon or of representing as attorney-at-law, or for furnishing legal advice, services or counsel to a person sued or about to be sued in any action or proceeding or against whom an action or proceeding has been or is about to be brought, or who may be affected by any action or proceeding which has been or may be instituted. in any Court or before any judicial body, or for the purpose of so representing any person in the pursuit of any civil remedy. Any corporation or voluntary association violating the provisions of this section shall be liable to a fine of not more than five thousand dollars and every officer, trustee, director, agent or employee: of such corporation or voluntary association who directly or indirectly engages in any of the acts herein prohibited or assists such corporation or voluntary association to do such prohibited acts is guilty of a misdemeanor. The fact that such officer, trustee, director, agent or employee shall be a duly and regularly admitted attorneyat-law, shall not be held to permit or ailow any such corporation or voluntary association to do the acts prohibited herein nor shall such fact be a defense upon the trial of any of the persons mentioned herein for a violation of the provisions of this section. This section shall not apply to any corporation or voluntary association lawfully engaged in a business authorized by the provisions of any existing statute, nor to a corporation or voluntary association lawfully engaged in the examination and insuring of titles to real property, nor shall it prohibit a corporation or voluntary association from employing an attorney or attorneys in and about its own immediate affairs or in any litigation to which it is or may be a party, nor shall it apply to organizations organized for benevolent or charitable purposes, or for the purpose of àssisting persons without means in the pursuit of any civil remedy, whose existence, organization or incorporation may be approved by the Appellate Division of the Supreme Court of the department in which the principal office of said corporation or voluntary association may be located."

At the same time the Legislature passed an act (Chapter ${ }_{4}{ }_{4} 8_{4}$, Laws of I909). forbidding the organization of business. corporations to practice law, furnish lawyers to others, etc. 
The case of Coöperative Law Co. (I98 New York) arose under this latter act and was carried to the Court of Appeals. Jurlge Vann, in writing the opinion of that Court, in speaking of title insurance companies, used the following language:

"It is not claimed that they prosecute or defend the rights of others but only their own, including such as the contract to indemnify gives them."

And it will be noted that the amendment to the Penal Law specifically exempts

"a corporation or voluntary association lawfully engaged in the examination and insuring of titles to real property",

but does this exemption go beyond the acts for which they are incorporated; does it permit them to go out into the highways and byways and solicit condemnation proceedings; does it permit them to undertake foreclosure and partition suits when they have no other interest in the proceeding than the collection of fees for legal services?

Does the exemption of "any corporation or voluntary association lawfully engaged in a business authorized by the provisions of any existing statute" mean that a corporation organized to sell groceries, which is a lawful act, may hire a lawyer by the year, and then rent him out, so to speak, to Tom. Dick and. Harry, at a profit?

Such questions are fully answered in the opinion referred to. Judge Vann further said in that opinion (and all the judges concurred with him):

"We agree with the learned counsel for the appellant that the vital question is whether prior to the Act of Igog a corporation could be lawfully organized to practice law. He claims that authority may be found in that part of the Business Corporations Law which provides that "three or more persons may become a stock corporation for any lawful business'. (Business Corporations Law, Sec. 2.) This means a business lawful to all who wish to engage in it. The practice of law is not a business open to all, but a personal right, limited to a few persons of good moral character, with special qualifications ascertained and certified after a long course of study, both general and professional, and a thorough examination by a state board appointed for the purpose. The right to practice law is in the nature of a franchise from the state conferred only for merit. It cannot be assigned or inherited, but must be earned by hard study and good conduct. It is attested by a certificate of the Supreme Court and is 
protected by registration. No one can practice law unless he has taken an oath of office and has become an officer of the Court, subject to its discipline, liable to punishment for contempt in violating his duties as such, and to suspension or removal. It is not a lawful business except for members of the bar who have complied with all the conditions required by statute and the rules of the Courts. As these conditions cannot be performed by a corporation, it follows that the practice of law is not a lawful business for a corporation to engage in. As it cannot practice law directly, it cannot indirectly by employing competent lawyers to practice for it, as that would be an evasion which the law will not tolerate. Quando aliquid prohibetur ex directo, prohibetur et per obliquium. (Co. Lit., 223.)

The relation of attorney and client is that of master and servant in a limited and dignified sense, and it involves the highest trust and confidence. It cannot be delegated without consent and it cannot exist between an attorney employed by a corporation to practice law for it and a client of the corporation, for he would be subject to the directions of the corporation and not to the directions of the client. There would be neither contract nor privity between him and the client, and he would not owe even the duty of counsel to the actual litigant. The corporation would control the litigation, the money earned would belong to the corporation and the attorney would be responsible to the corporation only. His master would not be the client but the corporation, conducted it may be wholly by laymen, organized simply to make money and not to aid in the administration of justice, which is the highest function of an attorney and counsellor at law. The corporation might not have a lawyer among its stockholders, directors or officers. - Its members might be without character, learning or standing. There would be no remedy by attachment or disbarment to protect the public from imposition or fraud, no stimulus to, good conduct from the traditions of an ancient and honorable profession, and no guide except the sordid purpose to earn money for stockholders. The Bar, which is an institution of the highest usefulness and standing, would be degraded if even its humblest member became subject to the orders of a money-making corporation engaged not in conducting litigation for itself, but in the business of conducting litigation for others. The degradation of the bar is an injury to the State.

A corporation can neither pactice law nor hire lawyers to carry on the business of practicing law for it any more than it can practice medicine or dentistry by hiring doctors or dentists to act for it. (People v. Woodbury Dermatological Institute, Ig2 N. Y., 454; Hannon v. Siegel-Cooper Co., I67 N. Y., 244, 246.) The legislature in authorizing the formation of corporations to carry on 'any lawful business' did not intend to include the work of the learned professions. Such an innovation with the evil results 
that might follow would require the use of specific language clearly indicating the intention. Recent legislation simply emphasizes and protects the established policy of the State and although $e x$ post facto tends to show that no such object was in contemplation when the general term 'lawful business' was used in the statute to authorize the formation of business corporations. (L. Igo9, chs. 483, 484). Business in its ordinary sense was aimed at, not the business or calling of members of the great professions, which for time out of mind have been given exclusive rights and subjected to peculiar responsibilities. All statutes relating to the same subject-matter must be read together and construed as parts of an entire system. When the provisions of the Code of Civil Procedure regulating the practice of law and the conduct of lawyers are read in connection with the clause of the Business Corporations Law quoted above, it is obvious that they do not relate to the same subject-matter and that in enacting the latter the legislature was dealing with something utterly foreign to the former. (Code Civ. Pro., Secs. 56 to 8I; Judiciary Law, L. I909, ch. 35). The special provisions relating to lawyers were not modified or affected by the general provisions authorizing the formation of business corporations".

(The above is as applicable to a corporation organized under the Insurance Law as to one organized under the Business Corporations Law.)

After quoting the above extract, Judge Betts, in Matter of Bensel, 68 Misc., said :

"An attorney's lien against a cause of action or the resultant verdict, judgment or award can only be successfully asserted and maintained by an attorney and counselor-at-law. This Award Company is not an attorney and counselor-at-law and it cannot, as the above case holds, act as such by employing competent lawyers to do the work which it claims to have done; in other words, it cannot do indirectly that which it cannot do directly."

In the Matter of City of New York, Avenue A, I44 App. Div., p. I07, one Bowsky made a contract which reads as follows:

"I do hereby retain and employ the ........... Company to act for me and in my behalf in the conduct of certain proceedings affecting my property, and to furnish such legal and other expert services as it may deem necessary in connection with the taking of my property by condemnation proceedings." ***

"And, in consideration of its services, do hereby promise, assign and agree to pay said ....... Company $33 \mathrm{I}-3$ per cent of whatever sum shall be allowed or paid for or on account of such taking; said percentage to cover all expenses and disbursements of every nature whatsoever." 
The Court held the agreement void, assigning as one of the reasons for so doing, that it was a contract to practice law.

And a second case of the same nature by the same company is Teported at 146 App. Div. Reports at p. I25; but I have never heard of anyone being prosecuted for violating the Penal Law in connection with this or any other similar contract.

In the ordinary accident insurance company contract the indemnity, or insurance, feature is simply an incident to the litigation in any event, and sometimes is not present at all. For instance, suppose that a single accident happens by which the holder of the contract becomes liable for the death of twenty persons. Judgment is obtained for ten thousand dollars in the first action. The defendant pays the ten thousand dollars; the company, in addition to defending the action, reimburses him for one-half that amount. The company has been defending its own interests, but it has likewise been defending the interests of the client. The second action results the same as the first. The company's liability, so far as it is an indemnitor, has now ceased, yet, under the contract it is compelled to defend the other eighteen actions in regard to which there is no liability as an indemnitor:

The contract provides that the company will defend all suits, although such suits are wholly groundless, false or fraudulent. There can certainly be no liability in such actions, other than the expense of defending them, which is what the company agrees to do, and in the Award Company contract and in the Patent Company contract the element of indemnity is not present, it is a contract to practice law indirectly which the Court in the above quoted opinion holds cannot be done, but which, nevertheless, is being dọne every day.

These companies employ agents who solicit business for them and receive a commission on the premiums or annual fees charged. If a lawyer were to employ agents to solicit contracts for him by which he, the lawyer, should agree to defend actions which might be brought against his solicited clients, for a certain yearly stipend, and to finance all such litigation, paying the disbursements and costs which might be taxed against the client, and to pay all judgments which might be rendered against them, to a limited extent, what would happen to the lawyer? How long would it take the grievance committee of some Bar association to ask for his removal from the Bar? 
I quote the first paragraph of the head note of a case entitled "Matter of Clark", reported in Vol. 184, New York Court of Appeais Reports, at page 222:

"I. CHAMPERTY-EMPLOYMENT OF LAYMAN BY ATTORNEYS TO PROCURE CLIENTS A MISDEMEANOR AND WARRANTS FORFEITURE OF OFFICE. Section 74 of the Code of Civil Procedure, prohibiting attorneys or counselors from procuring retainers by offering or giving any valuable consideration therefor, not only prohibits them from giving it to a desired client for the purpose of obtaining his claim to bring suit upon, but also from paying or agreeing to pay any layman, out of the prospective profits of cases, for services in inducing desired clients to place their claims in the attorney's hands for enforcement; such conduct is champertous and subjects the offending attorney to punishment as for a misdemeanor and also to removal from his office."

V.

One more fruitful source of income which corporate interests have discovered is the organization of corporations. A corporation is organized for the purpose of organizing other corporations, It may have a main office in some large city like New York or Philadelphia with branch, or statutory offices as they are called, in other states, particularly in those states which are blessed with easy incorporation laws; states in which the fees are low and limitations upon corporate acts are few. To understand the operation of these incorporate-you-while-you-wait-without-delayor-pain-foundries, it is necessary for the reader to know something of the method of bringing a corporation into the world, Corporation laws differ in detail in different States. Generally speaking, however, the method of organizing a business corporation is as follows:

Three persons sign a certificate, called the certificate of incorporation or charter, stating $(a)$ the name of the company, $(b)$ the names and addresses of the incorporators, $(c)$ the purposes for which it is inçorporated, $(d)$ the amount of its capital stock, (e) the number of shares, etc., and whether the stock is to be common or preferred, and perhaps other details. The certificate is filed with some State officer, usually the Secretary of State. A fee is paid, in some State depending upon the amount of authorized capital, in others not. The corporation is usually created for the purpose of taking over some business already established, 
either in fact or theory. The three incorporators are what are known as "dummies". That is, persons who have no interest whatever in the corporation. After the certificate of incorporation has been filed, a meeting of the incorporators is held for the purpose of organization. At this meeting a constitution and by-laws are adopted, officers elected, etc. A proposition is submitted by the real incorporator, who is thus far a stranger to the organization, offering to sell his business to the corporation for somany shares of its capital stock. The incorporators, in the exercise of superior wisdom and judgment with which an all wise Creator has endowed them, consider in solemn conclave the advisability of purchasing such business and, after deliberating on it long and seriously, as the minutes will show, they decide the assets, including the good will of the business, to be equal in value to the stock of the company, and accept the offer. Thereupon it is voted by the incorporators, who are the holders of all the stock which has thus far been issued, one share or possibly three shares each, to take over the business for stock. A bill of sale is made out by the owner of the new corporation, stock is issued to him in payment thereof, the real man behind the'gun is now a stockholder and one of the dummies resigns, the new stockholder is elected in his place and in about twenty minutes the business, formerly conducted by the individual, is now a corporation of which the same individual is the president and practically the sole stockholder. His clerk and stenographer, or perhaps his porter, being co-directors with him.

Perhaps his business is located in one State and he desires to incorporate in another where the fees are lower and restrictions. less arduous. The law of that State requires that the corporation shall have an office and principal place of business within the State. It also requires that at least one director of the corporation shall be a resident of the State. The advantages of the incorporating foundry now become apparent. It has an office in the "easy" State, it has two or three clerks in that office. It is set forth in the certificate of incorporation of the new company that its offices shall be at No. 2ro Blank Street, which is the office of the parent corporation. For allowing the new corporation to have a technical existence within its doors the parent corporation charges a fee of perhaps twenty-five dollars per year, and twentyfive more for furnishing one of its clerks as a resident director. In other words, the new corporation, for the payment of a mod- 
erate sum to the parent corporation, is provided with an office in the "easy" State, which office none of the real men constituting the corporation have ever seen and never expect to see, and it has a resident director who is simply a name, yet the law has been complied with and the corporation is now a complete full-fledged entity in the "easy" State.

Send one of these incorporate-you-while-you-wait outfits twenty-five dollars, they will draw your charter (they have them on hand all printed except the name), file your certificate, prepare your by-laws (also printed and on hand), and send you a handful of papers, waivers, notices, etc., which are about as intelligible to the lay mind as a Chinese puzzle. The victim is told to hold his meetings and go on doing business, perhaps the first meeting has to be held in the home State, then he is told the first meeting has been held and his corporation is ready to transact business. $\mathrm{He}$ feels happy till some official of his own State drops down on him and asks if his company has qualified itself to do business there. Then he realizes that the "easy" State is the expensive State after all.

Last spring a man came into my office with a bundle of this sort of junk under his arm and asked me to tell him as a favor where he was at. He had no money, he had spent it on the foundry whose State he had selected because it was cheap. I looked at his charter, which I recognized as a Maine form, and asked him who drew it up. He said it was drawn by a friend of his who used to work in a corporation office and knew something about law. He had sent it to the mill in the "easy" State (which was not Maine), they had taken it across the street and filed it, without advising him whether it was in proper form for their State, or not; perhaps they did not look at it; perhaps they would not have known whether it was in proper form if they had looked at it. For going across the street and filing the certificate, it had received twenty-five dollars and twenty-five dollars more for furnishing a resident director and the year's rent of an office, sufficient in size, grandeur and furniture display to comply with the law.

Immediately upon getting possession of this waste basket material, he had commenced selling stock at fifty cents on the dollar, contrary to the law of the State under which he had incorporated. (There is a way of doing this,-but that is another story.) All of the capital, if any was ever received from the unsuspecting 
public, was to be invested in the operation of a mine in a western State the laws of which impose heavier fees and taxes on foreign corporations than on their own. When I explained to him that it would cost him more to do business in the new State as a foreign corporation than it would to throw away his machine-made fiction and organize a new one in the State where he proposed to do business, he thanked me for my kindness and I have since been informed he raised money enough later on to pay another foundry to incorporate him anew in the western State where his undeveloped wealth is located.

These companies send out agents to solicit business, and advertise for it in the papers-it is a commercial proposition, nothing else.

The agent of one of these mills câlled on me a few days ago and explained its advantages as a help to the lawyer. Among other things, he advised me how to beat the tax collector. Said he, "We maintain a statutory office at ...... (naming a village I had never heard of, up the State), we control the village and they give us a low rate of taxation; they know if they do not, we will leave and they will get nothing from us. It is a great saving to large corporations." No doubt it is, but is there present any element of common honesty in claiming a backwoods village as the home town of a corporation which is physically located elsewhere? It may be a compliance with the letter of the law, but is it a compliance with the spirit of it?

This Company prints on its advertising literature, presumably as evidence of its high standing, the names of its directors, and after each name a few words telling who they are or their other connections. Opposite the first name on its list of directors appears in italics, "Former Atty. General of the United States". If the ex-attorney-general were to send out solicitors to bring in legal business to his unincorporated self, to his individual entity as distinguished from his corporate existence, and pay them for so doing, he would be a base violator of the Penal Code, at least, if he did it in New York. If he went out and made a personal canvass from house to house for legal work or stood on the street corner and said to the passerby, "Say, mister, please give a poor ex-attorney-general a case, I can handle it to the queen's taste," he might not be guilty of any violation of the Pena1 Law, which is so particular to circumscribe the lawyer's sphere of operations, 
but what is far worse, he would be guilty of violating that more holy law, the lawyer's Code of Ethics.

Listen to words which will enlighten you:

Question: May I know whether in the opinion of your committee it would be unprofessional for an attorney, who is the counsel for an association, to send out letters to a number of its members suggesting employment upon an annual retainer?

Answer: In the opinion of the committee it is desirable that such solicitation of business should be discouraged; the committee deems it unprofessional.

The above question was propounded to and the answer given by the Ethical Committee of the same association that dropped 869 poor devils from its roll because they could not afford the $\$ 10.00$ per year necessary to stay in.

The Legislature of New Jersey has recently passed seven bills curbing the trusts, which have been dubbed the "Seven Little Sisters". The foundries that maintain plants in that State are now advertising incorporating companies in Delaware and elsewhere. A sample letter recently sent to lawyers in New York by one of them, reads as follows:

\section{Re: CORPORATIONS.}

To Members of the Bar:

When you have occasion to organize a corporation in any State, we can be of assistance to you in supplying forms and precedents for charters, by-laws and minutes of organization meetings. Our coöperation will save you the time and expense of searching laws with which you are not familiar.

We furnish incorporators, resident director, agent for service of process, place for holding meetings, notify you of the time to file reports, notify you regarding States taxes and keep you posted as to all statutory changes affecting corporations in the State of organization for a small annual fee.

Le us demonstrate the value of our service when occasion arises. If you are interested, we shall be pleased to explain it fully without obligation.

Yours very truly,

And this in the face of a statute providing that

"It shall be unlawful for any corporation $* * *$ to furnish legal advice, services or counsel, or to advertise $* * *$ it has, owns, con- 
ducts or maintains $* * *$ an office $* * *$ for furnishing legal advice, services or counsel,"

and making it a misdemeanor

"for every officer, trustee, director, agent or employee of such corporation who directly or indirectly engages in any of the acts herein prohibited or assists such corporation to do such prohibited acts."

A few years ago the President of the United States sent to Congress a message in which he deplored the lax conditions of the corporation laws in the different States and recommended that some method be devised by which they could be brought under Federal control, with a view of getting away from such lax conditions. I took the liberty of calling his attention to the fact that the most liberal or lax laws governing corporations anywhere in the United States were the laws of the District of Columbia, for which the Federal Government was solely and alone responsible. Incidentally, I enclosed to him two advertisements clipped from a New York Sunday paper soliciting the incorporation of companies. The President referred my letter to the Attorney-General (not the one above mentioned) with the request that he investigate the subject and report back. The result of that report is contained in a supplemental message which the President immediately sent to the Senate and House of Representatives and which is as follows:

To the Senate and House of Representatives:

I have been informed that the attention of Congress has been drawn to the defects of the law authorizing the formation of corporations in the District of Columbia. The evils growing out of the existing law were brought to my notice by a member of the Bar of the District, and I directed the attorney-general to make to me a report upon the subject.

From that report it appears that in the past two years there have been incorporated under the law of the District 2,2I I companies, with a total authorized capital of nearly $\$ 4,000,000,000$. Many of the companies thus incorporated represent no actual investment, and may be used by unscrupulous persons to perpetrate frauds upon the public and upon those who may be deluded into investing in their stock. The increase of these corporations is going on with alarming rapidity. On one day last week one person presented for filing articles for the incorporation of fourteen companies. Another presented for filing articles of incorporation for thirty-eight companies. In each of these the same persons were named as trustees. 
The aggregate authorized capital proposed for these thirtyeight companies amounted to $\$ 43,000,000$. On one day of this week one person presented for filing articles of incorporation for fifty-four companies, in each of which the same three persons were named as trustees. The authorized capital proposed for these companies was over $\$ 300,000,000$. The attorney-general closes his report with the statement that-

"The law governing the formation and control of corporations in the District of Columbia is not, as it should be, a model of its kind, but on the other hand is hopelessly vicious."

The evil growing out of these laws is of such magnitude and the necessity for action is so urgent that I recommend to Congress the immediate consideration of the subject. The case calls for the most radical remedy. The right of incorporation ought to be suspended at once until Congress can devise proper legislation for guarding its exercise. Moreover, measures ought to be taken to annul the charters which have already been issued, either by their direct repeal, if that be possible under the Constitution, or by what other legislative action may be deemed necessary. I doubt not that Congress has already seen the necessity of replacing these vicious incorporation laws by those which are governed by sounder principles which will forbid the issuance of stock or bonds in excess of the actual investment and permit a proper public supervision. When such a law shall have been enacted all legitimate corporations which have been formed urder the existing law may readily be reincorporated.

The White House, January 30, 1905.

Theodore Roosevelt.

Such a condition could not have existed in the absence of the corporation factory.

The result of this message was to raise the ante; upon which these same foundries, factories, mills, or whatever they may be called, began advertising for incorporations under the laws. of Oklahoma, in their opinion the next easiest for separating the gullibles from their money.

If you, gentle, unsophisticated reader, would like to know how anxious these companies are to look after your corporate welfare, address a letter to the Secretary of State of some "easy" State, Delaware, Oklahoma, Arizona or Maine, for instance. Ask him to send you a copy of the corporation laws of his State, Before you receive his answer you will either receive a personal call or a communication through the mail from one or more of these ready-made incorporating shops. Whether they pay a consideration to some clerk in the office of the Secretary of State or 
whether some clerk or officer in the Secretary's office furnishes them with gratuitous information from the goodness of his heart, I cannot say, but it is, nevertheless, a fact that they will get to you before you receive the pamphlet from the Secretary of State's office.

Here is a fair sample of the "goblins 'll git you" game, as advertised in the current number of one of the West Publishing Company's publications:

INCORPORATE UNDER ..... LAWS.

Most liberal corporation laws in the United States. Private property exempt from all corporate debts. Keep offices and do business anywhere. "..... on How to Run a Corporation" free to companies incorporated through us. This is a well-bound law book of five hundred pages. It tells just what to do and how to do it. Also investigate our "Universal Corporate Record" Four books in one. No other like it. Free to companies incorporated through us. Cost incorporating very small. Write for free booklet containing ...... Corporation Laws, and it also tells you why, you should incorporate under the ...... Corporation Laws, and instructions in incorporating, and other valuable information, which you should have. "Free".

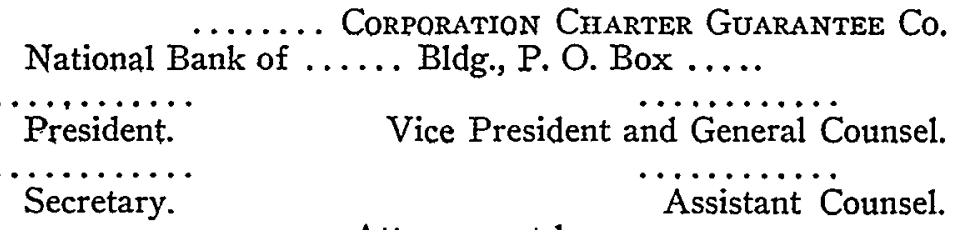

Attorneys-at-law.

The above is verbatim except the names of individuals and State, which I have omitted, as I am not writing a free ad. for the unwashed.

It may be better for society that titles be searched, that wills be drawn, that litigation be conducted and corporations organized, by corporations. It may be better for society that the lawyer be eliminated entirely. Then why not let the corporation appear as attorney of record in cases and do away with the legal fiction of having a lawyer appear as attorney for a party in a case when the real relationship of attorney and client does not exist, when the corporation is the real master and the lawyer a mere puppet in its invisible hands.

The Senate of the United States has recently recalled a Federal judge from the bench. The substance of the charges against 
him being that he clouded the wool sack with an air of commercialism. In Heaven's name, how can a judge help carrying to the bench with him an atmosphere of commercialism, if his training and environment is commercialism from the day he is admitted to the Bar till he leaves it for the bench?

The lawyer, as such, is being devoured by his own Frankenstein.

And, my good brothers in law, you who are still within the pale of the profession, unincorporated and free to think for yourselves, how do you like it? Shall we continue to practice law as a profession, honor its traditions, cherish and live up to its high ideals, and die poor, or shall we fall in line with our more progressive brothers, pass over into the business world-incorporate -exploit the public-and live rich?

Mr. Layman, you pay the bills under both systems, which do you like best?

George W. Bristol. 